\title{
From Red Scare to Capitalist Showcase: Working-Class Literature from Singapore ${ }^{1}$
}

Luka Zhang Lei

As a Ph.D. student in literature studies in Singapore, people often ask me about my focus of study. When I tell them that I research working-class literature in Singapore and other Asian countries, their very first reaction is always a perplexed look followed by a rapid fire of questions: "Who are the working class in Singapore? Do you mean workers can write literature?" Colleagues even dismiss my topic, stating, "Your project is so political, it sounds like a sociological investigation rather than literary studies. We don't do that here in Singapore."

These reactions, I believe, are conditioned by a significant lack of discourse on working-class literature in Singapore. The main aim of this essay, therefore, is to begin constructing such a discourse. I will do this by analyzing from a historical perspective three working-class writers from Singapore - Chong Han (1945-), Tan Kok Seng (1939-), and MD Sharif Uddin (I978-). ${ }^{2}$ By analyzing these very different writers, I will delineate a rudimentary historical overview of working-class literature in Singapore, stressing the different possibilities and limits under various "production modes.” In line with John Lennon and Magnus Nilsson's arguement in their first edited collection Working-Class Literature(s), I will not offer a decisive resolution of what constitutes Singaporean working-class literature, but rather, I will explore this literature through the lens of "what it could be" (Lennon \& Nilsson, 20I7, p. 203). My essay can offer new perspectives to Singaporean literature studies including contributing to the study of "history

How to cite this book chapter:

Zhang Lei, L. 2020. From Red Scare to Capitalist Showcase: Working-Class Literature from Singapore. In: Lennon, J. and Nilsson, M. (eds.) WorkingClass Literature(s): Historical and International Perspectives. Volume 2. Pp. I39-I64. Stockholm: Stockholm University Press. DOI: https://doi .org/Io.I6993/bbf.f. License: CC-BY 4.0. 
from below." In addition, my essay also contributes to the ongoing scholarly endeavours, of which this edited collection is an example, to map working-class literature from many countries and epochs from an international and comparative perspective.

In my first section, I analyze the works of Chong Han, a "farleftist" worker-writer who has been primarily considered a propagandist under the influence of the Cultural Revolution in China. I argue that this conception is not comprehensive, and instead I examine his works through a working-class literature perspective, opening new ways to understand his writing. In the second section, I discuss Tan Kok Seng and his works, which have been largely overlooked in Singapore literature studies, specifically examining why he has not been given much attention after his initial success in the I970s. The last section offers a critique of a recent cultural phenomenon in Singapore's literary scene, the Migrant Worker Poetry Competition. I argue that this form of producing commodified working-class writings-although complicated by working-class writers like MD Sharif Uddin-should be understood as a neoliberal experiment that potentially hurts the working-class writing community.

In each of the three cases I reflect on particular historical, socialpolitical, and aesthetic features that make visible the predicaments of working-class writers and various problems in the academic discourse on working-class literature at different stages in Singaporean history. Chong Han's literature and its (non-) reception makes visible the revolutionary struggles of the political left in Singapore and large parts of South East Asia that were eventually suppressed and defeated by right-wing nationalist movements. Tan Kok Seng highlights Singaporean colonial history: the manifold hierarchical relationships between the colonizers and the colonized, the efforts of decolonization, and the attempts to establish a post-colonial identity. And MD Sharif's work brings to the fore how the contemporary hyper-capitalist liberal free market economy where everything is commodified has made working-class literature in a lucrative competition. I hope this essay arouses additional perspectives and debates on workingclass literature and, in a broader sense, working-class studies in Singapore, and beyond. 


\section{The "Authentic" Working-Class Writer: Chong Han}

In their comparative study on working-class literature in Sweden and the U.S., Lennon and Nilsson describe this literature's marginalization in the U.S after the Cold War as a result of anti-communist fervor both at an institutional and individual level (Lennon \& Nilsson, 20I6, p. 48). A similar phenomenon can also be seen in Singapore, where the denunciation of Communist ideology has led to the rejection of working-class literature as a category of literary studies.

Worries about Communism have haunted Singapore since its colonization, ${ }^{3}$ continued after its independence in 1965 , and settled firmly in the national imagination after the establishment of a right-wing regime promoting a nation of "socialism without Communism" under the leadership of Premier Lee Kuan Yew and the People's Action Party [PAP].

As Hagen Koo states in Korean Workers: The Culture and Politics of Class Formation:

the state elites in South Korea, Taiwan, and Singapore are exceptionally powerful and autonomous of other societal groups. They possess extensive apparatuses of social control...The state elites in these countries have identified economic growth as the main basis for the legitimacy of the regime and have regarded autonomous labor organizations as inimical to economic development and political stability. (Koo, 200I, p. 7)

Concerning Singapore and the PAP, this observation is confirmed by Jastus M. Kroef who has analyzed the history of Communism in Singapore and Malaysia (Kroef, I967). In Singapore, the government routinely opposes Communists, instead promoting an ideology of multiculturalism ${ }^{4}$ which was adopted constitutionally when the state was founded (Huat, 2003, p. 75). Discourses about the working class disrupt the national narrative of achievements and prosperity. ${ }^{5}$ They have the potential to trigger social and political conflicts that risk destabilizing distinctions between cultures by showing that class conflicts run through ethnic and racial groups and that people of different cultures and places may have common class interests. Hence, it is not surprising that discourses on working-class literature are suppressed and mostly absent in Singapore. 
There is, however, a small body of research published in Chinese by scholars who are interested in working-class writing in Singapore. This scholarship focuses on left-inclined writers in Singapore in the I960s and I970s, suggesting that leftist literature has been minimized in more recent decades. I argue, however, that these studies tend to marginalize working-class literature as a literary category. For instance, in Malayan Chinese Left Literature: Under the Influence of Chinese Revolutionary Literature, I926I 976 (2009), Cheah See Kian examines literary works produced by worker-writers and leftist writers in Singapore with close affiliations to the political actions and policies of the leftist parties. He describes these works as being of the "Chinese cultural revolution literary type." Consequently, a working-class writer like Chong Han is regarded as being "far-radical," and his works are said to be "only” propagandistic. Choo Cheng Fatt's book Red Tide: The Cultural Revolution's Impact on Left Literature in Singapore has a chapter on worker's fiction, in which the influence from Maoism and the use of "political" language in novels is emphasized. Both Cheah and Choo see all workers' writings as manifestation of the rethoric of the Cultural Revolution and downplay its literary qualities. This is a reductive view, especially concerning Chong Han's works. By introducing the concept of working-class literature, I will highlight the significance of his work as literature, thereby opening up new perspectives on this era of Singaporean literature.

Chong Han（崇汉) is the nom de plume of Zou Xiqiu who was born in 1945 into a family of farmers in Pulau Tekong, an outlying island of Singapore. He graduated from Dunman Government Chinese Middle School, where he developed a strong interest in literature and writing. After his father died when he was still a child, he started working as a laborer. He published his first book, an essay collection titled Unyielding Spirit, in I972. It was just the beginning. Over five decades, Chong Han has published almost 20 books - ranging from essay collections, poetry collections, short stories to novels - all in Chinese. During this whole period, he worked in factories, on farms, in the shipping industry and as a bus driver. Grounded in his rich life experience, his texts are almost all associated with the lives of working-class people in Singapore, both the local Singaporean working-class and migrant 
workers from Malaysia and Thailand. His works have, however, gained very little attention, and Chong Han is not a critically examined writer. Interestingly, the publication of his works are mostly self-sponsored with some publications financed through personal loans.

Chong Han's writing displays changes over time, both in its ethos and its style. His production can be divided into three stages regarding content and form. In his first stage from 1972 to I98 I, a radical class consciousness informs his works. The texts report the hardships and the sufferings of working-class people in Singapore, stressing exploitation and oppression by capitalists, arguing for a fairer future for the working class. Another feature during this period is his condemnation and satirizing of powerful and wealthy people's evilness and hypocrisy. In the afterword to Unyielding Soul, for example, Chong Han (I972, p. 4I) determinedly states that he "can no longer hold back" his "passion to pick up the pen and declare war on this hideous society." 6

This ethos runs through all his writings during this period. His first novel, On the Glittering Road (I974), depicts workers' lives in the Singaporean Jurong industrial area from the perspective of the protagonist Di Yuan, who was born into a poor family and started working in a plywood factory after graduating from high school. While there, he witnesses harsh and oppressive working conditions. Not only does the factory owner exploit Di Yuan supervisors and coworkers also bully him. In spite of this, he is enlightened by some of his coworkers, among them Ya Juan, who actively organizes a cultural class for the workers and stresses the importance of working-class unity:

We are workers, as sisters and brothers, suffering from the same fate-exploited and oppressed by bigwigs and capitalists, who gained something for nothing, restrain us by all kinds of factory rules. If we want to take a leave, or see a doctor, the supervisors always embarrass us on purpose" (Chong Han, I974, p. 33 ).

The novel ends with most workers being dismissed from the factory because of their resistance against the wage contract. Ya Juan, one of the workers' leaders, is deported to her home country, Malaysia, and another leading figure is arrested. During his 
farewell conversation with Ya Juan, Di Juan expresses his new ethos: "I am willing to contribute my strength to the lofty calling of the people" (Chong, I974, p. I03).

Choo Cheng Fatt, a literary critic who has analyzed Chong Han's works, has stated that the plot and characterization in his novels are "formulaic and stereotyped." He argues that, as a result of his echoing the propagandist ideology of the Chinese Cultural Revolution, "the characters Chong Han created are dry and boring," and that "it is very common to see that in the workers' novels of this period, the writer attempts to stress typically heroic characters" (Choo, 2004, p. 66). The observation that Chong Han's books display "a strong note of the cultural revolution" is not without merits. Specific words and phrases used by Chong Han in his novels stem from the discourse of the Chinese cultural revolution; for example, he uses the term "cow ghost and snake spirt” (牛鬼蛇神) referring to the “evil” bourgeoisie. However, Fatt neglects that in many ways On the Glittering Road is a working-class Bildungsroman. I dispute the claim that Chong Han's characters are "dry and boring," since this seems to mean little more than that they are workers.

Throughout his work during this period, Chong Han continues to accentuate his characters as workers. In his novel In the Wind and Rain, which was published in I975, he presents the story of Yali, who is a working-class widower struggling with hardship at her job and her life as a mother of two children. He explains in the afterword of the novel that he attempts to give a picture of a bleak and miserable life while presenting a bright future that can be attained through workers' struggles. He also highlights the negative and dismissive attitudes of mainstream Singaporean writers and literary critics towards his works but remains adamantly defiant and determined to express the plight of the working-class in his writings:

A "complaining" piece of work "without thoughts and content" like this one, may indeed be dazzling for some so-called progressive and conscientious "poets" and "literati". It should have been thrown to "the place where it is supposed to be". Perhaps, I am ignorant and naïve. However, I was able to "get it out" there as I was able to with On the Glittering Road. 
Let "those people" shout loudly "boycott it! boycott it"! (Chong Han, I975, p. I 58 )

Chong Han's books from this period - Drums on the Equator 《赤道鼓声》(I972), On the Glittering Road 《金光道上》 (1974), and In the Wind and Rain 《在风雨中》(I975) - marked a revolutionary moment in the history of working-class literature in Singapore. By taking on the bourgeois literary establishment, Chong Han sees himself as partaking in class struggle.

In the second stage of his writings, between I98I and I997, Chong Han's works are less radical, and less associated with politics and class. Interestingly, in an interview published by the local newspaper Zaobao Weekly in 2003, the interviewer made the following comment: "It seems that you have written until I98 I and then stopped writing." Chong Han answered: "I didn't stop, I still keep on writing, but I have nowhere to publish my works." 7 With such concerns in his mind, Chong Han's writings steered towards a wider range of topics, extending to migrant workers in Singapore in the short story collections The Rough Road (I990) 《崎岖路》 and Dreams in the Foreign Land (1990)《异乡梦》 as well as in Yearning for Pulau Tekong Love (I992) 《恋念德光岛》a novel set in the island Pulau Tekong, that tells of its inhabitants before it was turned into a military training area for the Singaporean army.

It is not hard to see that Chong Han's works, both his fiction and his non-fiction, are inspired by his own life experiences. The novel Years of Wheelspin 《轮转岁月》( I990) tells of his five years as a bus driver and contains no overt political posturing. Rather, it portrays the meagre lives of bus drivers, their dealings with difficult passengers, and the burden of harsh company administrators. As the novel closes, the bus driver protangonist sees a "blue sky with white clouds" in his life after having undergone difficulties and hardships, signaling a bright future for himself and other fellow workers. In this novel, Chong Han is still captivated by the life of the poor and the working-class people often neglected in literary works.

From I998 until today, Chong Han's writing has transformed again, both in content and form. He has started to publish microstory collections, most of which are morally educational and religiously homiletic. At the end of the stories, he often conveys a 
moral, encouraging people to do good instead of committing sins in their life. Significantly, they do not have any strong connctions with specific working-class contexts. Chong Han has distributed a dozen of self-published micro-story collections to his friends, local libraries, and temples.

When I spoke with Wu Zhong (伍仲), a Singaporean Chinese writer and a friend of Chong Han, in the Singapore Chinese Literature Library which holds all of Chong Han's books, he frankly dismissed his friend's latest works, stating that his current writings have become moral education, destroying the small critical attention he received as a working-class writer. Yet, for Chong Han himself, it is a new turn in his writing career. In his book Let Nature Take its Course 《万事随缘》(I999), he said: “This short story collection ... is the brand-new starting point of my writing. It is a new beginning" (Chong Han, I999, p. I). His works of this period are less revolutionary and militant, yet he maintains that he has evolved rather than contradicted his earlier approach. Chong Han's works cannot be examined in detail here, nor can other contemporary left-leaning authors in Singapore such as Yuan Dian (原甸) and Huai Ying (怀鹰), who both had a considerable impact on Chong Han's writings. Still, this brief account will hopefully bring more attention to Chong Han's works and struggles, while beginning to illustrate the complexity of understanding Singaporean working-class literature.

\section{An Alternative Kind of Working-Class Literature: Tan Kok Seng}

While Chong Han and his works are viewed in the shadow of the "dark" history of Communism in Singapore, Tan Kok Seng and his works are something like a ghost haunting the history of colonial Singapore, not the least as a result of the nature of the "production mode" of his works.

Tan Kok Seng was born in I939 to a farmer family in Singapore belonging to the Teochew ethic group. His books Son of Singapore, Man of Malaysia, Eye on the World, Three Sisters of Sz, and the Chinese edition of Son of Singapore, Xinjiapo Zai 《新加坡仔》 were published respectively in I972, I974, I975, I979, and I985. ${ }^{8}$ 
The first three books are a trilogy of autobiographies, based on his life experiences, and Three Sisters of $S z$ is a novel set in Penang, Malaysia.

Son of Singapore was widely and well received after its publication in 1972, and "reviewers were quick to praise it . . he was celebrated as one of the country's Men of the Year by the New Nation newspaper" (Bosco 2013: iv). By I98 I, 25, 000 copies of the book were sold in English (Tan, I985, p. 3). ${ }^{9}$ However, the book fell out of favor and today, Tan's work is mostly ignored by literary critics and readers in Singapore. I propose four reasons for this erasure.

First, there is the peculiar aspect that his books are co-produced. As stated in the introduction to a re-printed edition in 2013 and $20 \mathrm{I} 6$ by the Singaporean publisher Epigram Books: “Tan's books had been all written first in Mandarin and afterwards 'rendered into English' in a collaborative effort with his former employer, Austin Coates, for whom Tan worked as a driver in Hong Kong." Because of this arrangement, some readers view Tan Kok Seng's books as mere byproducts, commissioned by a bourgeois British "employer," and do not consider him an individual writer in his own right.

I have no intention of defending Austin Coates, who does indeeed have a problematic colonial background. ${ }^{\circ}$ However, the relationship between Coates and Tan cannot be reduced to that of an employer to his employee, or, of a Western colonizer to an Asian coolie. Even if it's true that Tan's works are more or less influenced by Austin Coates, Tan Kok Seng himself claims the main authorship of his works and characterizes Coates' role as that of a supporter, declaring that "when I narrated my memoirs to my boss Austin Coates, he was very impressed, insisting that they were too interesting to be read only by my children. He urged me to publish in English" (Tan, I999, p. 5).

Secondly, Tan's works has tended to fall between the chairs in a literary life marked by divisions between cultures and languages. Given that his works were "rendered into English" from Chinese, they could be considered as "not really English" by those studying English literature and "not really Chinese" by those studying Chinese literature. Scholarly literature on Tan's works is scarce, 
and those who write about his texts are unsure of how to categorize them. For example, Ruth Morse argues that since they have been translated, it is difficult for her to even categorize them (Morse, I993, p. 62). On the Chinese language side, in the Curriculum Vitae of Singapore Contemporary Chinese Writers from 1965 to 2015, Tan Kok Seng's name does not appear at all. In another Chinese language resource, the Introduction to the Development of Modern World Literature (世界现代文学发展概论), he is introduced under the category of "Modern Singaporean Literature" and then subsumed under the "English Novel" along with Goh Poh Seng's works (Xiao, 2007, p. 20). Viewing his texts as working-class literature could thus give visibility to works that don't fit well within literary discoursens centered on, for example, language or ethnicity.

Thridly - and more importantly - unlike Singaporean "professional" writers of his period, such as Goh Poh Seng and Wong May, who are popular in English-writing circles, Tan had not received a higher education or studied overseas like other "professionals," and he has therefore always been identified as a laborer. In a Singaporean context, this has meant that he has been regarded as some sort of literary "amateur." This is a result of historical ideological conditions. The hegemonic ideological understanding of Singaporean literature included the idea that "real" writers were educated, and that, consequently, working-class writers should be placed outside of, or on the margins of, proper literature. Son of Singapore has been read as the autobiography of a coolie, and "even today, on the National Book Development Council's database of Singapore writers, he is described as a 'writer and laborer" (Bosco, 2013, p. iv). This highlighting of the fact that he is not a "full-time" writer stops his reception as a serious literary figure in Singapore.

Lastly, Tan Kok Seng seems to have silenced himself for financial reasons: "Sadly in some ways, but typical of his natural pragmatism, Kok Seng declared in 1985 that he would write no more, since his primary concern was to make his own living and see his son and daughter through a proper education" (Sharp, 20I3, pp. xii-xiii). However, Tan Kok Seng did not necessarily view this as an exodus from literature because he did not regard himself as 
a professional writer: "I only obtained primary school education, the use of the words in my work cannot compare to experienced literary people" (Tan, I985, p. I ${ }^{\text {II }}$. Thus, he seems to have internalized the bourgeois idea of workers as not belonging to the realm of "proper" literature. Introducing the concept of working-class literarure in a Singaporean context might help combat this classist understanding.

Here, we may ask, what makes a working-class writer after all? Can we read Tan Kok Seng as a working-class writer and his works as working-class literature? And if so, why? To answer these questions, we have to explore the connections - and the significance thereof - between authors' backgrounds and life experiences and their writings. Some argue that it is only a member of the working class who can produce working-class literature. Yet, some scholars, such as Lennon and Nilsson, find this benchmark worrisome: "For many critics, the authorial background of a writer has become an essential criterion, making the aesthetic qualities of a text secondary-categorization depends on whether or not the author speaks 'authentically' from a working-class position” (Lennon \& Nilsson, 20I6, pp. 40-4I). Tan Kok Seng's literary works, however, display that an emphasis on a writer's working-class background might disturb certain ideological stereotypes about literature and its limits. Thus, in this context, a definition of working-class literature emphasizing the authors' working-class backgrounds can be very valuable. That such a definition contradicts the self-understanding of a writer such as Tan Kok Seng, who does not view himself as a "real" writer, only underscores how complex this term is as a categorization.

Also when it comes to literary content, the concept of working-class literature might contradict Tan Kok Seng's selfunderstanding, at the same time as it makes visible important aspects of his works. In his recent writings, he displays more "family consciousness" than class consciousness. In the preface to Son of Singapore, he specifies: "Autobiographies are not often written by Asians. It is somehow difficult for an Asian to expose himself and his inner workings in public. However, I hope my children and my readers will learn from my books the value of hard work" (Tan, I999, p. 5). And through the dedication of the 
Son of Singapore "To my children," he once more explicitly refers to his children as the addressees of his book.

Nevertheless, it is important to acknowledge that his works belong to a "people's history," and to the history of the working class in Singapore. His book details his difficult life as a coolie which he became at age fifteen simply for financial need. As a coolie, he had to cope with the exploitation by a harsh SingaporeanChinese boss who treated him dreadfully and frequently shouted at him: "I've never seen such a stupid idiot as you;" or, "I've never seen such a stupid boy as you" (Tan, 20I3, p. 62). These descriptions vividly and personally present a demanding and cruel life.

Man of Malaysia, Tan Kok Seng's second autobiography, first published in 1974, documents his life after he moved from Singapore. In the book, he represents himself as always ready to reinvent himself in different social circumstances. As Sharp describes him, "Here is a person who can float serenely through lives of the wealthy and privileged, quite unlike his own as a famer turned coolie turned chauffeur turned soap salesman turned vegetable seller and poultry dealer" (Sharp, 2013, p. v). All the while, Tan Kok Seng appears too busy to reflect deeply upon political and historical events. His writing shows little historical consciousness. In fact, even the historic decolonialization of Malayasia goes unnoticed by the young Tan Kok Seng. He writes: "Unbeknownst to me, in 1963, Malaya had expanded into the Federation of Malaysia, with the inclusion of three former British Crown Colonies" (Tan, 2013b, p. 1 57). Only later in Man of Malaysia does the birth of Singapore as an independent country become significant and Tan Kok Seng's recognition and conception of Singapore has seemingly drastically changed. After having watched Lee Kuan Yew's speech on the television news on 9 August 1965, Tan Kok Seng confidently expresses his emotions: "Our nation was born. We ourselves were only one drop of its blood. Yet I shall never forget that evening" (Tan, 2013b).

Ilsa Sharp believes that Tan Kok Seng "has no angels, no hidden meanings, indeed little subtlety. He is what he is: a naif" (Sharp, 2013 , p. v). In my view, however, Tan Kok Seng is not so much “a naif", but, unlike Chong Han who is heavily equipped with class consciousness and is a self-recognized working-class writer, Tan 
Kok Seng sees his everyday struggles and working experiences from a distinctly personal rather than political perspective.

The linguistic richness in Tan Kok Seng's depiction of everyday life reflects the multicultural and multilingual spheres in the history of Singapore. It presents a linguistic hybridity and diversity embedded in his only seemingly "simple" depictions of daily life. In its complexity, it differs from the "particular kind of multiculturalism" which is often narrowed down in the "Singapore story" told through National Education in schools and in commonsense narratives in the media" (Holden, 2008, p. 35 I). In Tan Kok Seng's life writing, we can perceive that "the constant interweaving of languages and linguistic levels contribute to erosion of some of the compartmentalization of multiracialism: governing strategy is subverted by the realities of tactical, everyday practice in individual lives” (Holden, 20I2, p. 26). Tan Kok Seng writes "people's history" by recovering subjective experiences and by reconstructing the "small details of everyday life" (Samuel, I98I, p. xviii). It may be different from the political writing of Chong Han but to explore working-class literature in Singapore, scholars must explore writers like Tan Kok Seng.

\section{Working-Class Literature and Neoliberal Capitalism: MD Sharif Uddin}

Whereas the above writers have been marginalized in Singapore, working-class writing has recently become part of an important and highly visible cultural phenomenon in the country's contemporary literary scene. Since 20I4, the Migrant Worker Poetry Competition, initially organized by Shivaji Das and his team, has been held annually. ${ }^{12}$ Through this competition, many literary works by laborers (mainly migrant workers) have been published. Generally speaking, two types of literary works have thus emerged: a) multi-lingual poetry collections by a number of different migrant workers such as Songs from a Distance and b) literary works written by individual writers, such as Stranger to Myself by Bangladeshi worker MD Sharif Uddin.

Although positive attention to working-class literature is welcome, I take issue with the fact that it occurs within the capitalist 
logic of the cultural industry. The organizer of the Migrant Worker Poetry Competition, Shivaji Das, emphasizes that "winners and participants from the event have been showcased in platforms such as the Singapore Writer's Festival, TEDx, poetry slams with local poets, video documentaries, and dance recitals at the Esplanade, Singapore." Given this statement, it seems that the leading motive of the competition is "showcasing" the workers. From my point of view, this reveals a capitalist paradox: When workers' literature, and their critique of exploitation, is promoted in this way, the workers, and their literary works, are once more exploited, this time by a capitalist literature industry.

I find it especially worrisome that working-class literature is presented though the form of a competition. If the aim, as the editor of Songs from a Distance stated, is to give "a voice to the workers," why is there a need to pit writing workers against each other? In which sense does this competition differ from traditional ways of producing and maintaining power and prestige? Most importantly, when examining the overall framework for presenting these workers' voices, I have found that the competition promotes itself by emphasizing the workers' identities without addressing specific class-related issues.

This highlighting of identity (and, implicitly, of identity politics) underscores an important debate within working-class literature studies. Identity politics has a very strong position globally (Di Stefano, 20 I 7, p. I 39). In Singapore today, The Migrant Worker Poetry Competition is conducted in such a way that the language of "class" is missing. Rather, the competition connects closely to a neoliberal discourse of self-success and achievements by celebrating and promoting a few "selected" migrant workers and their works.

Given the "foreign" nature of the migrant workers, the competition primarily calls for Singaporeans to become aware of and emphathize with "foreign" labor. Vanessa Lim, the editor of Songs from a Distance, has stated that literature can act as a medium to draw back the curtain from many workspaces: "These poems offer readers a glimpse into the thoughts, hopes, and dreams of Singapore's invisible workforce" (Lim, 20I7). Indeed, the "invisibility" of labor vitally inspired the competition, which aimed at 
"giving voice to a community that needs to be heard" (Yeo, 20I7). However, while the intention may be laudatory, it is contradicted by the very form of the competition. William Davies (20I4) has noted this phenomena in a different context:

Rhetoric and theories of competition and competitiveness have been central to neoliberal critique and technical evaluations from I930 onwards. To argue in favor of competition and competitiveness is necessarily to argue in favor of inequality, given that the competitive activity is defined partly by the fact that it pursues an unequal outcome.

Davies' keen observation indicates a crucial point: Competition is central to the neoliberal discourse, and aligns itself with inequality. More specifically, the paradox within competitions lies in the form itself, inasmuch as "an organized competition involves contestants being formally equal at the outset and empirically unequal at the conclusion" (Davies, 20I4).

Moreover, the structure of a competition also serves to justify the capitalist market and its power. In this sense, we may argue that the Migrant Worker Poetry Competition seemingly discovers and promotes workers' writing competence and talent, yet the organized competition itself as a form can be regarded as homogenizing "workers voices" to a certain standard set by the practices and rules of the competition.

Tobias Werron shows in "Why Do We Believe in Competition?" that "the modern competitions are based on social processes that mediate between the performance of the competitors and the appreciation of the audience. It thus draws attention to rarely considered prerequisites of the production and distribution of 'audience goods' such as attention, legitimacy, and prestige" (Werron, 201 5, p. I93). In the light of these observations, we may better understand why Shivaji Das favored competition and passionately endorsed this format: "The contest has received widespread recognition in both international and Singaporean media such as the BBC and The Straits Times. TODAY, a local newspaper, chose the contest as one of the top IO art events in Singapore in 20I4" (Das, 2017). Perhaps, for Das, the significance of the contest is largely measured by the distribution of "audience goods." In this 
case, the competition is centrally about the event's ranking and social media coverage. How, though, does this event impact actual migrant workers? Imagine a migrant worker in Singapore who is truly interested in reading books and hoping to acquire a copy of Songs from A Distance. Could he or she possibly afford to buy it, as the book costs $\$ 25$ and the average daily wage is only around \$I 8 to $\$ 30$ ? ${ }^{\text {I3 }}$

Not surprisingly, I found that Songs from A Distance also has a well-designed website where people can make orders and payments online. The question and answer section of the website provides the answer to "where does my money go?" for potential consumers. It explains, "All proceeds will go towards supporting migrant worker causes, such as the work undertaken by Transient Workers Count Too (TWC2) and future iterations of the Migrant Worker Poetry Competition. The production costs for Songs from A Distance have been generously sponsored by Potato Productions." At first glance, consumers may think that their money for the book will directly benefit the workers. As a matter of fact, however, to an unspecified extent, the money supports the organizers and the production of future competitions. Moreover, the costs of the book "has been generously sponsored by Potato Productions," a group of Singapore-based enterprises who deal with technology innovations and digital mobility. The company labels and markets itself with the slogan "be creative, do good, have fun." By sponsoring Songs from a Distance, the company can thereby build up its own marketable philanthropic brand identity.

Apart from the form of the competition, there is another layer of a contradictory dynamic within the Migrant Worker Poetry Competition which identifies it as existing within a consumercapitalist framework. The organizers and some editors of the migrant workers' poetry collections play the pivotal in-between role between the writers and consumers, or, so to speak, between production and consumption. In a way, they need to constantly be involved with creating the "value" and importance of the new commodities, justifying consumers reading and buying these books. Through the efforts of such cultural intermediaries the writings of migrant workers is legitimized within the capitalist 
market and for a capitalist readership. Pierre Bourdieu effectively describes this process, "see[ing] the new cultural intermediaries as germane to the 'ethical retooling' of consumer capitalism and its promotion of a 'morality of pleasure as duty'" (Nixon \& Gay, 2002, p. 497).

The working-class literature generated by the cmpetitions is a symbolic sign that carries the moral message of the petite bourgeoisie and the dominant class: it is crucial to showcase the migrant workers in various platforms as a sign of "concern" and "sympathy" for the working-class and other less privileged people. By giving prizes to some selected ones, the organizers, the editors, and even the judges, role-play as filter and "taste-maker" in this industry. Henceforth, it is the cultural intermediaries who outline and structure the possibilities for this new type of "working-class literature" in the age of consumer capitalism while simultaneously regulating and profiting from the worker's writings from production to consumption.

Working-class literature that is not dependent on capitalist institutions may be able to withstand cultural hierarchy and capitalist legitimation. According to Bourdieu, "the only area of working-class practices in which style in itself achieves stylization is that of language, with argot...for example, the intention of deriding and desacralizing the 'values' of the dominant morality and aesthetic" (Bourdieu, I984, p. 395). It is to be feared that the capitalist version of migrant workers' literature cannot achieve this "stylization" when every piece of such writing has to be first selected through a competition system and then filtered by the cultural intermediaries. Further, the goodwill and tolerance of the cultural intermediaries bring to the fore Jean Baudrillard's remark on "functional tolerance," which indicates that in our society today, for something to be produced and consumed, "our relating simply falls under the sway of industrial production and fashion...those who were once mortal enemies are now on speaking terms, that the most fiercely opposed ideologies 'enter into dialogues'" (Baudrillard, I998, p. I90). It is not likely that a working-class literature that fights against capitalism in order to change the workers' living conditions will succeed within a competition regulated by capitalist entities. 
Of all the works produced by these competitions, Stranger to Myself has received the most critical attention. It was published in Singapore by local publisher Landmark Books in 2017 and subtitled The Diary of a Bangladeshi in Singapore. The book contains prose and poems written between 2008 and 2016 and translated into English from Bengali, recording MD Sharif's life as a migrant worker in Singapore. In the forward to his book, the well-established Singaporean poet and literary critic Gwee Li Sui writes: "How Goh Eck Kheng, the publisher of Landmark Books, and I discovered Sharif is a story in itself. I was compiling short works for a literary anthology on Singapore's modern history, which was published as Written Country in 2016...Goh and I looked for a suitable voice among previous top entries in the fledgling Migrant Worker Poetry Competition" (Gwee, 20I7, p. I I). Gwee's statement, in my view, echoes what I have mentioned above: a rather typical and somewhat prejudiced literary critic's perspective of working-class literature. On the one hand, the editors indeed acknowledged the importance of migrant workers' voices and writing for Singapore's modern history by including Sharif in the book. On the other hand, though, what the editors desired was simply "a suitable voice." Most importantly, they were looking for someone among "previous top entries in the fledging Migrant Worker Poetry Competition." Seemingly, to include a migrant workers' voice to literature of Singapore's history, a "suitability" is rightly required.

Angus Whitehead wonders, in his reflections on Bengali workerpoets in Singapore: "As may have been the case with Md Mukul Hossine in Me Migrant, are poets edited and translated for local consumption in Singapore's preconceived image of migrant workers, and their more complex, ambitious, controversial works not deemed suitable, or saleable for publication in Singapore? (Whitehead, 20I7). In Sharif's case, there is a similar contradiction. Unlike Tan Kok Seng who dedicated his books to his children and saw them rather as a personal record for the family, Sharif's writings are "respectfully dedicated to the memory of $\mathrm{Mr}$. Lee Kuan Yew, founder of modern Singapore," and he points out, "After about a decade here, I, like other migrant workers, have many stories and recollections to share with you" (Sharif, 20I7, p. I3). Unlike Tan Kok Seng's works, Sharif's text is confidently addressing its potential readers. 
The book mainly covers three motifs: his daily experience as a worker in construction sites, his bitter life experiences in Singapore, and his longings and nostalgia towards home and family. True, to read Stranger to Myself is to read a book of pain and struggles. While perusing the poignantly hurtful stories and poems, we may conjure up Sharif's statement in the preface: “This diary contains the collected fragments of my experiences. It is not my intention to write anything against my homeland or this country. No hurt feelings, please" (Sharif, 20I7, p. I3). From my perspective, this declaration is more or less related to the tremendous impact of "publication" on Sharif as a migrant worker-writer in Singapore. In a way, the preface is inconsistent with the work's narrative. My observation speaks to what Whitehead expressed in his study:

Perhaps these poets have consciously or unconsciously adopted a politic strategy (that perhaps we all adopt in this place, this climate infected with something vaguely akin to fear) by editing and policing themselves, writing poetry here in which anything concerning the more controversial, morally reprehensible aspects of their treatment as exploited migrant labor without which uber-capitalist Singapore would not be where it is today, are shied away from, not confidently engaged with in detail? (Whitehead, 20I7)

Sharif's writings from 2008 to 2016 is full of descriptions of and anger toward exploitation and mistreatment of workers. For instance, in the essay "The Tears of Workers," written in 20I0, he cries out: "Why are we still ashamed of reminding the company of our rights? Why do laws speak hesitantly about us laborers? Why do workers still suffer despite the massive progress of civilization? Where is the so-called humanity" (Sharif, 20I7, p. 48)? In many of the other essays, Sharif calls into question the inhospitable conditions migrant workers face on a daily basis.

Sharif discloses the physical and psychological predicaments of migrant workers. The food he has to eat is scarce and going bad: "We eat Io to I 2 hours after it is cooked and the food smells rotten in the hot weather." There is no guarantee for workers' safety: "He (the company owner) just thinks about productivity. He doesn't think seriously about the safety of the workers." There is a shared hopelessness with the coworkers: "The two workers with me were sad and I saw them crying silently. What is helplessness? I have seen the perfect definition" (Sharif, 20I7, p. 65). The 
pain he suffers, indeed, serves as the most predominant theme of the Sharif's writings.

Apart from descriptive documents on everyday struggles and life experiences, Sharif's book also contains poems about a variety of topics, ranging from personal reflections and family issues to public events. In many of his poems, we can trace a very strong sense of being a “migrant.” In “A Worker's Journey," he ends with these lines:

At times I belong to this country

At times to that

I run, I have to run

We may say that the time he actually feels as if he is belonging to "this country" is the time when he is a worker, owned by the company as labor. Thus, he struggles to "run" and to be a real human. In line with the title of the book, Stranger to Myself, Sharif's writing poignantly displays a process of worker "alienation" in Marxist terms, particularly regarding the relation between his dehumanized subjectivity and class relations.

Nevertheless, MD Sharif Uddin is just one of the "representative" migrant worker writers from Singapore. "Selected" through a migrant workers writing competition, Sharif displays the possibility of migrant workers publishing literary work in the age of rampant globalized capitalism. His descriptions of migrant workers' suffering in Singapore is poignant, stressing issues of the terrible working-condition and injustices. Yet, the "production mode" of his book greatly re-shaped his narrative. Published under these material conditions, it is, of course, better for him to have "no hurt feelings" given that he is situated in such a vulnerable position. Although he writes of the workers as a collective, academics and media fervently celebrate him as self-made individual migrant worker writer, placing this text securely within a petite-bourgeoise literary site.

\section{A Concluding Remark}

By discussing the three working-class writers above, I have delineated a historical overview of working-class literature from Singapore, stressing above all the sucession of various "production 
modes." Each writer manifests a different facet of Singaporean history. Chong Han's works remind us of the struggles and the pain working-class people suffered for the newborn nation. They express his hope for equality and justice and his compassion for miserable yet industrious people in Singapore and beyond. The (non-) reception of his works reveals several issues within academic discourse, including the lack of critical attention to working-class literature, the disdainful and biased attitude towards "communism"-related topics, and the vast chasm between literatures of different languages in Singapore.

Tan Kok Seng's autobiographies recount the rich experiences of a laborer and in many ways represent a "people's history" of Singapore. Unlike Chong Han, Tan Kok Seng is not equipped with political consciousness. He does not claim to speak for anyone else but wished to tell his personal story to his children and his wife. His success in the I970s reveals a certain government ideology. Tan's story fits into the larger narrative of the "Singapore story": starting from a poor family background, then working hard, having a family, and eventually becoming a proud "Son of Singapore". Meanwhile, the future silencing of Tan Kok Seng reveals how the site of literature in Singapore is dominated by classist bourgeois ideals: A writer who is a worker is always regarded as "too simple" and his works as having "too little aesthetic value."

In MD Sharif Uddin's writings, he offers his painful and brutal experiences as a migrant worker in Singapore. Although - or because - he is not a "real" Singaporean, the production and promotion of his work raises several issues about Singapore, and about the fate of migrant workers from Asia in an age of extreme capitalist exploitation and inequality. Sharif's work was produced through competition and translation. This mode of production helped him become published as a worker-writer while simultaneously constraining him.

In this essay, I only focus on writers who have a working-class background. More concretely, they are all laborers who have toiled hard (too hard in my view). However, this is not to suggest that working-class literature ought to be confined in this way. I hope that this essay invites more discussion and scholarship on working-class literature from Singapore and Asia. Apart from 
these three male workers, I believe that there is also the "herstory" of female workers' writings, and the working-class writings from other ethnicities and languages still tend to remain unexamined. It is just a beginning; there is still a long and winding way to go. However, I do hope that I have been able to demonstrate that the concept of working-class literature does have the potential to disrupt established discourses about literature in Singapore - and beyond - and thus to widen our understanding of it.

\section{Endnotes}

I. I am grateful to Prof. Kevin Riordan for his advice. I also wish to thank Prof. Magnus Nilsson and Prof. John Lennon for their valuable comments and kind support.

2. Literature in Singapore is written in the country's four official languages, namely, Chinese, English, Malay and Tamil. My study, however, examines only works published in English and Chinese. I hope to include more working-class writers writing in other languages in my future research.

3. Singapore came under direct British control as a colony in $\mathrm{I} 858$. During the Second World war, Singapore was occupied by Japan from I942-I945. Singapore gained independence from the British Empire in 1963 and became a fully sovereign state in 1965.

4. Of the residential population in Singapore, 75 per cent are ethnic Chinese, I7 per cent ethnic Malays, 7 per cent ethnic Indians and a small category of 'Others' (Huat 2003: 62).

5. In 2017, Singaporean scholar Teo Yeo Yen published her remarkable book This is What Inequality Looks Like. She decribes the the dominant nationalist narrative of a "Singapore Story" as follows: "This is the story we tell ourselves about ourselves: Singapore became in a matter of a few decades a shining Global City. We were poor and now we are rich. We had no natural resources and now we can eat whatever we want, buy whatever we want, right in our own city. We were uneducated and now our children score among the highest in the world on standardized tests. We are safe, we are clean, we are amazing. We are amazing. We are amazing” (Teo 2019: 43).

6. All translations from Chinese are my own. 
7. The original interview can be found in the appendix of the book Hong Cao, xinhua zuoyi wenxue de wenge cao by Choo Cheng Fatt. (Red Tide: The Cultural Revolution's Impact on Left Literature in Singapore).

8. Tan Kok Seng published his books in English in the "Writing in Asia Series" by Heinemann Educational Books (I966 to I996). In total, there are II 4 books in this series with a wide range of topics and diverse writers. The initiation of this series was "credited with contributing prominently to creative writing and the creation of a shared regional identity amongst English-language writers of Southeast Asia”.

9. My translation. As Roth Morse has observed: "And this is a remarkably successful book-though I would like to have more than the figure 20,000 copies, since a book as congenial to government policy may have had help along the way from pricing and distributing" (Morse I993: 64).

Io. During the Second World War, Austin Coates served in the Royal Air Force intelligence service in South East Asian countries, and after the war, he moved to Hong Kong in I949 as an assistant colonial secretary and magistrate for the Hong Kong government. Afterwards, he also worked respectively in Singapore and Malaysia. In I962, Coates decided to devote his life to professional writing. He is an author of many books including fictional works such as City of Broken Promises (1967) and The Road (1959) and historical books such as A Macao Narrative (1978) and Macao and the British, I637-I842 (1988). He also published Rizal: Philippine Nationalist and Martyr in 1968.

I I. My translation from the Chinese.

I2. On Shivaji Das personal website, he introduces himself: "Writer, traveller, and photographer; Shivaji Das is the author of 'Off the Beaten Track: Collecting Stories of Unheard Lives,' Yoda Press (under publication), 'Journeys with the caterpillar: Travelling through the islands of Flores and Sumba, Indonesia,' and 'Sacred Love: Erotic art in the temples of Nepal,' Mandala Publications/ Adarsh Books. Shivaji is the conceptualizer and lead organizer for the acclaimed Migrant and Refugee Poetry Contests in Singapore and Malaysia and for the Global Migrant Festival”. See: https://www.shivajidas.com. 
I3. In Stranger to Myself, MD Sharif Uddin states, “The lowest price of lunch packs in the canteen is not less than $\$ 4$. To a lowly worker like me who earns \$I 8 per day, \$4 seems like \$400” (p. 6I).

\section{References}

Baudrillard, J. (1998). The Consumer Societ.: Myths \& Structures. London, Sage Publications.

Bosco, D. (2013). "Introduction." In Tan, K. S. Son of Singapore. Singapore, Epigram Books.

Bourdieu, P. (1984). Distinction. A Social Critique of the Judgment of Taste. Translated by Richard Nice. Cambridge, Mass: Harvard University Press.

Cheng, Y. (20I I). "The Chinese Cultural Revolution and the Decline of the Left in Singapore." Journal of Chinese Overseas, 7 (2), pp. 2 II -246.

Chong, H. 金光道上.(I974). On the Glittering Road. Singapore, 人民文艺出版社.

Chong, H. 在风雨中. (I975). In the Wind and Rain. Singapore, 人民文艺出版社.

Chong, H. 万事随缘. (I999). Let Nature Take its Course. Singapore, 热带出版社.

Chong, H. 恋念德光岛.(I992). Yearning for Pulau Tekong Love. Singapore, 长屋出版社.

Choo, C. F. (2004). Hong Cao, xinhua zuoyi wenxue de wenge cao (Red Tide: the Cultural Revolution's Impact on Left Literature in Singapore). Singapore, Lingzi Media Pte Ltd.

Crompton, R. (1998). Class and Stratification. An Introduction to Current Debates. Cambridge, Polity Press.

Das, S. (20I7). Songs from a Distance. Singapore, Potato Productions.

Davies, W. (20I4). The Limits of Neoliberalism. Authority, Sovereignty and the Logic of Competition. London, Sage Publications.

Debord, G. (2005). Society of Spectacle. London, Rebel Press. 
Dutta, M. (2017). "Migration and Health in the Construction Industry. Culturally Centering Voices of Bangladeshi Workers in Singapore." International Journal of Environment Research and Public Health, I4 (2), pp. I32-I 46.

Gwee, L. S. (2017). "Foreword”. In Sharif, MD. U. Stranger to Myself. Diary of a Bangladeshi in Singapore. Singapore, Landmark Books.

Hochschild, A. (1983). The Managed Heart. Commercialization of Human Feeling. Berkeley, University of California Press.

Holden, P. (20I2). "Refusing the Cultural Turn: Amir Muhammad's Politics of Surfaces", in Beyond East-West Binaries in (Auto) Biographical Studies. Edited by Maureen Perkins. Honolulu: University of Hawai'i Press, pp. I 5-34.

Holden, P. (2008). Autobiography and Decolonization: Modernity, Masculinity and the Nation State. Madison: The University of Wisconsin Press.

Huat, C. B. (2003). "Multiculturalism in Singapore: An Instrument of Social Control." Race \&́ Class, 44 (3), pp. 58-77.

Koo, H. (200I) Korean Workers. The Culture and Politics of Class Formation. Ithaca \& London, Cornell University Press.

Lefebvre, H. ( I99I). The Production of Space. Oxford \& Cambridge, Basil Blackwell.

Lennon, J. \& Nilsson, M. (2016). "Defining WorkingClass Literature(s). A Comparative Approach Between U.S. Working-Class Studies and Swedish Literary History". New Proposals. Journal of Marxism and Interdisciplinary Inquiry, 8 (2), pp. 39-6I.

Lennon, J. \& Nilsson, M. (2017). “Afterword”. In Lennon, J. \& Nilsson, M, eds. Working-Class Literature(s). Historical and International Perspectives. Stockholm, Stockholm University Press, pp. I97-206. DOI: https://doi.org/Io.I6993/bam.h

Merrifield, A. (2006). Henri Lefebvre. A Critical Introduction. New York, Taylor \& Francis.

Morse, R. (I993). "Novels of National Identity and Inter-National Interpretation." College Literature, I9/20 (3/I), pp. 60-77. 
Nixon, S \& du Gay, P. (2002). "Who Needs Cultural Intermediaries?" Cultural Studies I6 (4), pp. 495-500.

Samuel, R. (198I). "Introduction: People's History", in People's History and Socialist Theory. Edited by Samuel Raphael. London: Routledge and Kegan Paul, pp. xv-xxxix.

Sharif, MD. U. (2017). Stranger to Myself. Diary of a Bangladeshi in Singapore. Singapore, Landmark Books.

Sharp, I. (2013). "Introduction” In Tan, K. S. Man of Malaysia. Singapore, Epigram Books.

Tan, K. S. (201 3a). Son of Singapore. Singapore, Epigram Books.

Tan, K. S. (201 3 b). Man of Malaysia. Singapore, Epigram Books.

Tan, K. S. (I999). Son of Singapore. Singapore, Longman Singapore Publishers.

Tan, K. S. (1985). 新加坡仔. Singapore, Heinemann Educational Books (Asia).

Werron, T. (2015). "Why Do We Believe in Competition? A Historical-sociological View of Competition as an Institutionalized Modern Imaginary". Distinction. Journal of Social Theory, I 6 (2), pp. I86-210.

Whitehead, R. (20I7). "“this migrant soul enrich this earth'. Encounter with Migrant Bengali Poetry in Singapore," Singapore Unbound [online]. Available at: https://singaporeunbound .org/blog/20I7/6/ıo/18j705n9rdw6qbci6iokkkpkoinf8r [Accessed 3 August 2020].

Xiao, F. (2007). Introduction to the Development of Modern World Literature 世界现代文学发展概论. Shenyang: Liao Hai Publishing House. 